Occultations of Aldebaran are on record as far back as the year A.D. 49I ; it is stated in the Chinese Annals that the star was occulted at Nankin on March 29. Apparently the first occultation observed in Europe was found by Bullialdus in a Greek manuscript, which thus describes it:-"Anno 225 Diocletiani, Phamenoth 15 in 16 , vidi Lunam sequentem claram Hyadum post accensas lucernas, digiti unius ad sumnam semisse. Videbatur autem occultasse ipsam. Stella quippe apposita erat parti, per quam bisecatur limbus Lunæ illuminatus." Bullialdus makes the date A.D. 509, March I I, and an approximate calculation shows that he is correct. New moon fell about 7 h. G.M.'T. on March 6.

ENCKE'S CUMET. - This comet at its present return will be observable in these latitudes in the carly evening hours before perihelion. The following ephemeris is for 6h. G.M.T. :-

\begin{tabular}{|c|c|c|c|c|c|c|c|c|}
\hline \multirow{2}{*}{\multicolumn{2}{|c|}{$\begin{array}{l}1885 \\
\text { Jan. I }\end{array}$}} & \multicolumn{3}{|c|}{ R.A. } & \multicolumn{2}{|r|}{ Decl. } & \multicolumn{2}{|r|}{$\begin{array}{l}\text { Log. distance from } \\
\text { Earth }\end{array}$} \\
\hline & & $\begin{array}{l}n \\
\therefore 2\end{array}$ & $\begin{array}{l}m . \\
55\end{array}$ & 25 & $\ldots$ & $-1357 \cdot 8$ & $\ldots$ & $\begin{array}{ccc}\text { Harth } & \text { Sun } \\
0.1526 & . & 0.1309\end{array}$ \\
\hline 2 & $\ldots$ & 22 & 56 & 18 & $\ldots$ & 40.5 & & \\
\hline 3 & $\ldots$ & 22 & 57 & 12 & $\ldots$ & $3 \cdot 4$ & & \\
\hline 4 & $\ldots$ & 22 & $5^{8}$ & 7 & $\cdots$ & 46.5 & & \\
\hline 5 & $\ldots$ & 22 & 59 & 3 & $\ldots$ & 49.8 & $\ldots$ & $0.1500 \ldots 0.1120$ \\
\hline 6 & $\ldots$ & 23 & 0 & I & $\ldots$ & $4 \times 3 \cdot 3$ & & \\
\hline 7 & $\ldots$ & 23 & I & 0 & $\ldots$ & 416.9 & & \\
\hline 8 & $\ldots$ & 23 & 2 & 0 & $\ldots$ & $420^{\prime} 7$ & & \\
\hline 9 & $\ldots$ & 23 & 3 & 2 & $\ldots$ & 4247 & $\ldots$ & $0.1462 \ldots 0.0917$ \\
\hline Io & $\ldots$ & 23 & 4 & 5 & $\ldots$ & $428 \cdot 9$ & & \\
\hline II & $\ldots$ & 23 & 5 & Io & $\ldots$ & $433 \cdot 2$ & & \\
\hline 12 & $\ldots$ & 23 & 6 & 17 & $\ldots$ & 437.7 & & \\
\hline 13 & $\ldots$ & 23 & 7 & 25 & $\cdots$ & $442^{\circ} 4$ & $\ldots$ & $0.1410 \ldots .0699$ \\
\hline 14 & $\ldots$ & 23 & 8 & 35 & $\ldots$ & $447^{\circ} 2$ & & \\
\hline 15 & $\ldots$ & 23 & 9 & 46 & $\ldots$ & $45^{2} \cdot 2$ & & \\
\hline 16 & $\ldots$ & 23 & Io & $5^{8}$ & $\cdots$ & 4573 & & \\
\hline 17 & $\ldots$ & 23 & 12 & 12 & $\ldots$ & $52 \cdot 6$ & $\ldots$ & $0.1344 \ldots 0^{0.0463}$ \\
\hline 18 & $\ldots$ & 23 & I3 & 27 & $\ldots$ & 58.0 & & \\
\hline 19 & $\ldots$ & 23 & 14 & 44 & $\ldots$ & $5 \quad 135$ & & \\
\hline 20 & $\ldots$ & 23 & 16 & 2 & $\ldots$ & $519 \cdot x$ & & \\
\hline $2 I$ & $\ldots$ & 23 & 17 & 20 & ... & 5248 & ... & $0.1261 \ldots 0.0206$ \\
\hline 22 & $\ldots$ & 23 & I8 & 4.0 & $\cdots$ & $530 \cdot 7$ & & \\
\hline 23 & $\ldots$ & 23 & 20 & I & $\ldots$ & $536 \cdot 6$ & & \\
\hline 24 & $\ldots$ & 23 & $2 \mathrm{I}$ & 24 & $\ldots$ & $542 \cdot 6$ & & \\
\hline 25 & $\ldots$ & 23 & 22 & 47 & $\ldots$ & $548 \cdot 7$ & $\ldots$ & $0.115^{8} \ldots 9^{\circ} 9926$ \\
\hline 26 & $\ldots$ & 23 & 24 & II & ... & $554 \cdot 8$ & & \\
\hline 27 & $\ldots$ & 23 & 25 & 37 & $\ldots$ & $6 \mathrm{I} 0$ & & \\
\hline 28 & & 23 & 27 & 4 & $\ldots$ & $6 \quad 7^{\circ} 2$ & & \\
\hline 29 & .. & 23 & 28 & $3^{I}$ & ... & $6 \div 35$ & $\ldots$ & $0^{\circ} 1033 \ldots 9.9619$ \\
\hline 30 & $\ldots$ & 23 & 30 & 0 & $\ldots$ & 6197 & & \\
\hline $3^{I}$ & $\ldots$ & 23 & 31 & 29 & $\ldots$ & $+625^{\circ} \mathrm{O}$ & & \\
\hline
\end{tabular}

The intensity of light expressed in the usual manner is 0.27 on January $\mathrm{I}$, and $0^{\prime}{ }_{5} \mathrm{I}$ on the last date of the ephemeris.

\section{GEOGRAPHICAL NOTES}

AN interesting roject was laid before the Associated Swiss Societies of Geography at their meeting at Berne last month, by M. Millhaupt. He suggested the formation of an international geographical bureau foc the following purposes :-(I) To carry out the resolitions arrived at by the International Geographical Congresses. (2) To mahe exchanges cvery month, or oftener if need be, between the eighty odd geographical societies; in place of each society sending its own publications in eighty different directions, it would only have to send them all at once to the burcau, which would do so. This, le claims, would save both time and moncy. (3) To publish, in the four or live principal languages, a summary of the contents of the publications of the various ge graphical societies; instead of each society being forced to do this for itself, a single examination would suffice to put them all au contrant with what has been done all over the globe. There would in this way be the further advantage of knowing what was published by societies like the Geographical Society of Japran, the publications of which are in a language not generaily known in Europe. M. Muillhaupt thought that the idea was not a difficult one to be carried out; the expense would be shared by the numerous societies interested. These contain approximately 38,000 active members, and doubtless the countries having an interest in the pr gress of the geographical sciences would take part in a central organisation of the nature here suggested.

THE last number (Band xi. No. 8) of the Verhandlun;en der Gisellschaft fïr Erilkunde au Birlin contains two papers on
West Africa : one accompanied by an excellent map, by Herr Flegel, of his recent journey along the Niger to Adamawa; the other, by Herr Reichenow, on the Cameroons, and the German colony there. Dr. Lopez writes on the Argentine States, and the importance of the German element in the foreign population there.

THE investigation of the subterranean course of the Re a River ha:s been actively pursued for some time past by the Coast Section of the German and Au trian Alpine Society. The Reka is that mysterious river which, coming from the Schneeberg in Carniola, loses itself in the caves of the Karst, and after a subterranean course of more than thirty kilometres, breaks out of the ground near San Giovanni di Duino, is then called the Timavo, and eventually flows into the Bay of Monfalcone. Already, on March 30 last, a lart of this subterranean course was investigated by a party starting from the village of St. Canzian, where a celebrated cave is situated, into which the Rcka f: 1ls with thundering noise when the water is high. In Scptcmber a second exploration was made. The first subterranean cave is called the Rudolfstome ; it was from here the explorers started in two boats. First, they passed a canal about sixty metres in length, very narrow, and bounded by rocky walls one hundred metres in height; then a large cave was reached, where the party landed and fastened the boats, as waterfalls and rapids p,revented further progress in boats. The underground journey was now continued on the rocky banks, the river being crossed several times on ladders. Thus six waterfalls were passed, and a seventh was reached. Altogether the explorers penetrated to a distance of between two and three hundred metres underground.

Bulletin No. 5 of the U.S. Geological Survey is, Sciance remar's, a dictionary of altitudes in the United States, compiled by Henry Gannett, chicf geographer of the Survey. It is essentially sn extension of the "Lists of Elevations," prepared by the same author for Hayclen's Survey; but, with the present broader organisation of the Geological survey, the lists now appropriately include the whole country, while the earlier editions were concerned chiefly with the region west of the Mississippi. A list of authorities fills eight pages, and railroad abbreviations occupy eight more; then the States and stations follow alphabetically, the number of altitudes given being about 18,000 . It is stated thar the collection of railroad profiles for Pennsylvania is exceptionally complete and admirably adjusted, making the portion of the dictionary referring to that State by far the fullest and most satisfactory. By an unfortunate oversight, it is not stated whether the base level is high, mean, or low tide.

AT the recent meeting of the Ethnological Section of the Imperial Russian Geographical Society a paper was read describing Adrianow's journey through the Altai Mountains in 1881. The traveller was only able to takc four companions, on account of the meagre funds at hi; disposal; nevertheless he was able to obtain excellent results, and to penetrate hitherto unknown regions. Although the southern slopes of the Altai Range have already been the object of investigation of various students, such as Pallas, Ledeluur, Humboldt, and others, the eastern part of the region, the vast districts between the River Tom and the Government of Yenisci, have been almost a tore incognita. Adrianow's expedition started from the town of Kustnetsk, crosted the River Lebed, examined Lake Teletsk, touched Chulshman, Jan, and Agalan, crossed the Shanshal Pass, advanced to the River Kemchik, and sought for and found the sources of the Yenisei. They travelled through the region through which the river flows to the town of Yeniseisk, where the expedition came to an end. Throughout the journey Rus ians were found only around the sources of the Yenisei and on the River Usg. The population of the Altais is composed of sectaries who emigrated thither during the last century; their existence was wholly unknown until $\mathbf{1 8 6 8}$, when they were by rhance discovered by a Russian officer who was surveying there. $\Lambda$ drianow met similar colonies at Tobut on Koko-nor. These were founded in 1800 . The colonists are described as savage and predatory. Besides these the traveller visited the so-called Black Tartars, on the rivers Koudoma and luida $-a$ tribe which has only once before been visited and described. They are regarded as descendants of the great Finnish and Turanian tribes, but hardly anything in an anthropological sense is known about them. The travellers also brought back a considerable number of pictures of monuments and works in stonc, which exist among the Sajans and in Mongolia. Those of monuments to the dead are very interesting; some of them are merely 
conical heaps of stones, while others are laid quite flat and are surrounded by a circle of larger stones; a third kind exhibit a primitive art of stone-cutting, the stoncs bearing a distant resemblance to the human body. Frequertly around the graves the bones of horses which had been brought as sacrificial offerings, were found, as were also certain Runic in criptions.

M. AdRIANow, in his journey through the Altais, notices the existence in these regions of immigrant communities which have been forgotten and which have been re-discovered by chance. It is also reported from St. Petersburg that a similar discovery has been made elsewhere in Siberia. In the course of a prolonged inspection of his province, the Governor of Irkutsk (GrovernorGeneral of Eastern Siberia?) came across a town called Ilim, with 500 inhabitants, 150 houses, and four ancient churches, with remarkable relics of Cossack times. It is stiil under the republican rule of a vitche, or public assembly, convoked by a bell, as in old Novgorod the Great, although the new municipal institutions were supposed to have becn applied to that part of the Empire ten years ago. Not one of the inhabitants can read or write.

An important geographical work on Austro-Hungary is now being prodiced in parts by Mr. Alfred Hölder, the publisher, of Vienna. The author, Prof. Umlauft, gives in alphabetical order the names of the various States and peoples of the Austro-Hungarian empire, as well as those of the more important districts, mountains, rivers, and towns, with their meanings. He does not, however, confine himself simply to present names, but also gives the forms employed formerly and the various changes which the name has undergone from the earliest times down to th: present day. The work is thus historical and philological. The total number of names treated will be between six and seven thousand. The first part, which ha appeared, contains IO4I names, from Aa to Donau. Geographical names, it is said, not only have their history, they are themselves pieces of history. The distinction between the German and Slav names of places is characteristic. The great majority of the German village names are connected with those of persons, probably the founders or original owners, more rarely with that of the patron saint. Thus Simmering comes from Simoning, Hütteldorf from Utendorf, Hadersdorf from Hadrichsdorf, Kallssburg from Chadalhohisperg (i.e. mountain of one Chadalhoh), Domsdorf from Dominiksdorf. The change wrought in course of time in some names has been very great, and renders their explanntion difficult. The Slav names, on the other hand, are mostly taken from the position of the place or some peculiarity in the neigh. bourhood. They also manifest great stability of form, and it is only in their Germanising that they have materially altered. Thus the Czech Brloh becomes in German Bierloch, Ratibor Rothwurst, and Radoina Rothweim. The Czech Lhota, which means simply a settlement which is free from taxation, assumes in German such various forms as Oehlhiitten, Elhotten, Ellgoth, Wellhotten, Welhuitten, Wellhiitten, Mehlhiittel, Malten, and others. Even real German names have undergone the same eccentric change, and names which in their original form are quite clear in their meaning have by a slight change become incomprehen ible; thus Donnersmark is really Donnerstagmarkt, or Thursday Market. It may be remembered that some articles in the Times during the autumn, followed by a long correspondence, did much interesting and valuable work of this kind for English place-names, though of course in a less regular and systematic form.

Mr. IM ThurN's Romaima expedition left Kalacoon on October I 5 with three boats and crews of seventeen Pomeroon and two Mazarooni Indians, and on the following day they ascended the first falls of the Essequibo. Simultaneously with their departure from Kalacoon, an expedition for Roraima, under the charge of a commercial botanist named Siedel, left Bartica for Roraima viâa Mazarooni. The two parties will probably meet on the mountain.

M. Aymonier, a Saigon official, has recently returned fro $n$ a journey of exploration in Indo-China. He left Saigon at the end of September last year to explore Southern Laos, and made a collection of the ancient Cambodian inscriptions. Having explored the intervening country, he reached Bangkok at the end of June last, and here he reinained for some time to complete his studies on the Siamese kingdom. The result of his travels will shortly be published in the "Excursions et Reconnaissances," and he will aft rwards proceed on another journey of exploration in Annam.

\section{ROOTS}

I $\mathrm{N}$ treating of the roots of plants this cvening, I may request you to dismiss from your minds any expectations or apprehensions of marvellous descriptions of tropical or rare roots on the one hand, or of a list of the peculiarities of various kinds of roots or so-called roots on the other, though it is not improbable that some of the facts will be, in part at least, new to some of you, as they certainly are to many people. I do not propose even to put any new discoveries before you. It has seemed much more to the purpose to show, as well as time will permit, that a vastamount of interesting and important information can be derived from a proper and systematic study of the roots of a common iplantinformation, moreover, which is important alike to the scientific botanist and to the practical agriculturist, two people who find they have more and more in common each day they come to know one another better. As the diagrams must in part have told you already, I propose that we meet on ground familiar, to a certain extent, to every one ; and the sequel will show, I hope, that we have in no way acted unwisely in taking cach other into confidence on the subject of an ordinary root, such as is well known to all of us. So much is this the case, that our study may be confined for the most part to the root of the common broad bean and a few other plants of our gardens.

[The lecturer then shortly described the germination of the common bean, maize, and a few other plants, and illustrated by diagrams the mode in which the first or primary root of the bean seedling emerges below, as the young seedling shoot (or "plumule") prepares to force its way upwards to the light and air. Next followed a short consideration of what this root may be said to be.] Anticipating matters to a certain extent, it may be shortly described as an organ for fixing the rest of the plant to the substratum, or soil, from which it absorbs certain foodmaterials. By confining our attention to this typical and wellknown form of root, we may avoid any complexities resulting from the consideration of the more extraordinary cases occurring among the lower plants, or among curious ac̈rial epiphytes, parasitic or otherwise, and other abnormal forms-forms which would demand several lectures by themselves.

The roots we have to consider, then, are organs for anchoring the rest of the plant firmly into the soil, and for absorbing certain matter dissolved in water from that soil. Obviously, we may do well to see, fi'st, how the root gets into the soil; and secondly, how it accomplishes its objects when there.

When the young root first peeps forth from between the coats of the seed, it is seen to have its tip directed downwards towards the centre of the earth. Now this is not an accident; for if the seed be turned over, so that the apex of the root is made to turn upwards, its tip soon bend; over, and again becomes directed downwards. [Mr. Ward then proceeded to explain, as shortly as could be done without detailed experimental evidence, that this persistent turning earthwards of the young root is due to a peculiar property, almo $t$ of the nature of a ensitiveness or perception to the influence of gravitation, and is not due merely to the weight of the organ.]

Next, evidence has been obtained to show that the tip of the root has a slightly rocking or swinging movement, which is more or less of the nature of the movements so well known in the case of the stems of twining plants ; the tip of the root, in fact, not only moves earthwards, but tends to describe a very steep spiral as it does so. These successive very slight noddings to all sides of the tip as it proceeds in a line directed towards the centre of the earth are extremely slight, it must be borne in mind, but they may aid the point of the root to wriggle its way between the particles of earth in a loose soil, or to run down any crevice or hole it meets with.

Thirdly, in addition to its determined tendency to descend, though in a very slightly spiral course, the tip of such a root as we are describing has been found to be peculiarly sensitive to the contact of solid bodies. This extremely curious phenomenon could only be fully described by references to experiments and matters which we have scant time for. It must suffice, therefore, to state that there is evidence to show that the extreme tip of the root, on coming in contact with a hard resistant body, is caused to turn aside from that body, and if it comes simulta. neously into contact with two bodies, one of which is harder than the other, it is caused to bend away from the harder of the

I Abstract of a lecture delivered before the Manchester Horticuitura Society, in the old Tow: Hall, Manchester, on November 6, by H. Marshall Ward, M.A., Fell $>$ w of Chri $\rightarrow t^{2}$ ' College, Cambridge, and Assistant Lecturer in Botany at the Owens College 